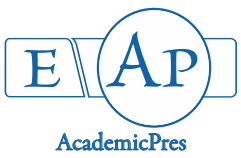

Falana MB and Nurudeen QO (2020)

Notulae Scientia Biologicae 12(1):57-73

DOI: $10.15835 / \mathrm{nsb} 12110541$

Research Article

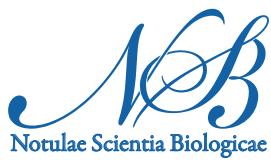

\title{
Analysis of secondary metabolites and in vitro evaluation of extracts of Carica papaya and Azadirachta indica leaves on selected human pathogens
}

\author{
Mansurat B. FALANA*, Quadri O. NURUDEEN
}

Al-Hikmah University, Department of Biological Sciences, Ilorin, Nigeria; bolman4ever@yahoo.com (*corresponding author)

\begin{abstract}
Extraction of the leaves of Carica papaya (family Caricaceae) and Azadirachta indica (family Meliacea) were done using solvents with varying polarities (acetone, hexane and ethylacetate). The crude extracts were screened for phytoconstituents using the preliminary method and high-performance liquid chromatography (HPLC) for separation and quantification of the constituents. Susceptibility of three medically important microorganisms (Staphylococcus aureus ATCC 25923, Escherichia coli ATCC 25922 and Candida alblicans) to the solvent extracts was tested at $100 \mathrm{mg} / \mathrm{mL}, 50 \mathrm{mg} / \mathrm{mL}$ and $25 \mathrm{mg} / \mathrm{mL}$ concentrations the disc diffusion technique. Tannins, saponins, alkaloids, steroids, flavonoids and anthraquinone were present in all the solvent extracts of $A$. indica and C. papaya. Protein was present in all the solvent extracts of $A$. indica but absent in all the solvent extracts of $C$. papaya. Terpenoid was only present in hexane extract of $A$. indica but absent in other solvent extracts of $A$. indica and $C$. papaya. Flavonoid was present in all but only absent in ethylacetate extract of $A$. indica. Glycoside was present in all but absent in hexane extract of $A$. indica. Coumarin was only present in acetone extracts of both plants and absent in other solvent extracts of the two plants. Extracts of Carica papaya and Azadirachta indica displayed varying inhibitory activities (between $5.00-15.00 \mathrm{~mm}$ ) against the organisms at all the tested concentrations. Acetone extract of $A$. indica produced zones of inhibition ranging from 5.00-14.00 mm while acetone extract of $C$. papaya produces a range of 4.00-10.00 mm. Also, hexane extract of $A$. indica produced inhibition range of 7.00-10.00 $\mathrm{mm}$ whereas hexane extract of $C$. papaya produces a range of 5.00-15.00 mm. However, ethylacetate extract of $A$. indica produced inhibition range of 5.00-13.67 $\mathrm{mm}$, while ethylacetate extract of $C$. papaya produce a range of 5.00-15.00 $\mathrm{mm}$. Different compounds quantified as different peaks by HPLC in the different solvent extracts of Carica papaya are acacic acid, genistein, protodioscin, betulinic acid, phorbolester, creptolepinone, brusatol and alpha ionone while the fractions from the solvent extracts of Azadirachta indica are myricetin, azadirachtol, azadirachtin a, pentadecane, phytol, azadirachnol, quercetin, $\mathrm{b}$ caryophyllen, alpha ionone, ascaridole, trams.b.farnes. Results obtained in this work indicated that all the solvent extracts of Carica papaya and Azadirachta indica contained active phytoconstituents and the extracts displayed good potentials at preventing diseases associated with the microorganisms tested in this work.
\end{abstract}

Keywords: Candida albicans; Escherichia coli; Myricetin; Protodioscin; Staphylococcus aureus 


\section{Introduction}

Indiscriminate use of antibiotics in human and veterinary healthcare system has led to the emergence of multi-drug resistant (MDR) strains of microorganism which pose greater threat to the global public health (Goyal et al., 2008). The more realistic perception of the limitations of orthodox medicines in terms of cost, accessibility, effectiveness and safety (Shariff, 2001) has driven researchers to source for plants with medicinal properties for the development of new antimicrobial substances to which microorganisms have not yet developed resistance.

Most parts of the developing countries accept and rely on herbal medicine due to the belief of better compatibility with the human body and fewer side effects (Mohammad et al., 2010). It has been estimated that about 35,000 to 70,000 plants are used as medicinally out of over 400,000 plants species reported worldwide (Bibi et al., 2011). Plants have an almost limitless ability to synthesize aromatic compounds and secondary metabolites, most of which are phenols or their oxygen-substituted derivatives that can be used to treat chronic as well as infectious diseases (Boligon et al., 2012).

Even though hundreds of plant species have been tested for antimicrobial properties, the vast majority of them have not been adequately evaluated (Mahesh and Satish, 2008). Azadirachta indica commonly known as Neem, from the family Meliacea is traditionally called Dogonyaro in most parts of Nigeria. Since the discovery of Vernonia amygdalina years back, there has been enormous information on the medicinal value of this plant. However less than $10 \%$ of the world's flora has been studied chemically in detail to determine their active constituents (Ekam et al., 2010).

Carica papaya Linnaeus is an herbaceous succulent perennial plant with self-supporting stems. It is from the family Caricaceae, a common plant used medicinally in Nigeria and it is commonly called Ibepe in Yoruba, Gwanda in Hausa and Okwulu Oyibo in Igbo. In traditional medicines, papaya leaves have been used as a treatment for malaria (Titanji et al., 2008). Also, scientific reports have revealed that C. papaya possesses immunomodulatory, antimicrobial, anti-inflammatory, antihelmintic, anticancer, wound healing, antifertility, abortifacient, diuretic, anti-hypertensive and antimalarial properties (Gurunga and Škalko-Basnet, 2009; Amazu et al., 2010).

Even though hundreds of plant species have been tested for antimicrobial properties, the vast majority of them have not been adequately evaluated (Mahesh and Satish, 2008). Also, many researchers have reported the influence of different extraction solvents and techniques on the content of natural antioxidants in extracts (Michiels et al., 2012). Hence, this study involves testing for the effects of different solvents on the active constituents and the antimicrobial potentials of Azadirachta indica and Carica papaya which are some of the well tolerated, readily available and affordable plants locally in Nigeria.

\section{Materials and Methods}

\section{Collection and preparation of plant materials}

Fresh leaves of Carica papaya and Azadirachta indica were collected from Apalara Area, Ilorin, Kwara state, and authenticated at Herbarium Unit of Department of Plant Biology, University of Ilorin where were voucher specimens were deposited (Azadirachta indica - U/LH/003/860 and Caricapapaya-U/LH/004/967).

These plant materials were washed with tap water in order to remove the dust, dried under the shade at room temperature for 2-3 days and powdered with electric blender (Master Chef Blender, Model MC-BL 1980, China). About $10 \mathrm{~g}$ powdered material of each plant species was variously soaked in $100 \mathrm{~mL}$ solvent of acetone, hexane and ethylacetate extract for 48 hours with regular shaking and then filtered (Alain et al., 2010). The filtrates were then evaporated under reduced pressure $\left(45 \pm 10^{\circ} \mathrm{C}\right)$ using the rotary evaporator $(\mathrm{Model} \mathrm{RE}$ 
Zhengzhou, Henan, China). All extracts were stored in different sterile and labeled glass bottle at room temperature until screened. Percentage yield of the extract was calculated and recorded. They were kept in the refrigerator at $4{ }^{\circ} \mathrm{C}$ until needed for analysis. Sterility of the extract was tested by serially diluting $1 \mathrm{~g}$ of each extract up to $10^{-1}$. A quantity $(2 \mathrm{ml})$ of the extract solution was inoculated into $10 \mathrm{~mL}$ of Muller Hinton broth, incubated at $37^{\circ} \mathrm{C}$ for 24 hours and checked for clarity as an indication of sterility. Stock solutions of corresponding crude extracts were prepared in dimethyl sulfoxide (DMSO) (Perez et al., 1990), from which 2fold serial dilutions was used to prepare three different concentrations $(100 \mathrm{mg} / \mathrm{mL}, 50 \mathrm{mg} / \mathrm{mL}$ and 25 $\mathrm{mg} / \mathrm{mL}$ ) of each solvent extract of the plant extract.

\section{Pathogenic microorganisms}

The pathogenic microorganisms Staphylococcus aureus ATCC 25923, Escherichia coli ATCC 259220 and Candida albicans were obtained from Microbiology Laboratory of University of Ilorin Teaching Hospital, Ilorin, Nigeria. The bacteria were collected on nutrient agar slant while fungus was collected on Sabouraud dextrose agar. Each was re-cultured on fresh nutrient agar and Sabouraud Dextrose Agar plate for purity. Their morphology and Gram staining were carried out to confirm their identity (Ochei and Kolhatkar, 2008).

\section{Preparation and loading of discs}

Paper discs were prepared from Whatman No. 1 filter paper. The discs were labeled and autoclaved for 15 minutes at $15 \mathrm{lbs}$ pressure. They were allowed to cool, transferred into air tight Bijou bottles and kept in the refrigerator. Approximately $20 \mu \mathrm{l}$ of each of $100 \mathrm{mg} / \mathrm{mL}$ concentration of each solvent extract was loaded on the discs using a mechanical pipette. More discs were loaded with same amount from $50 \mathrm{mg} / \mathrm{mL}$ and $25 \mathrm{mg} / \mathrm{mL}$ of each plant extract. All the impregnated discs were allowed to fully dry for 24 hours under a laminar flow cabinet (Basri and Fan, 2005), they were stored in airtight Petri dishes at $20{ }^{\circ} \mathrm{C}$ till they were ready for use (Jawetz and Adelberg, 2004).

\section{Antibacterial and antifungal activities of acetone, ethyl acetate and hexane extracts of leaves of $A$. indica and} V. amygdalina

Standardization of inoculums was achieved by aseptically using sterile wire loop to transfer colonies from the agar slant into $5 \mathrm{~mL}$ Mueller-Hinton Broth (MHB) and Sabouraud Dextrose Broth (SDB) for bacteria and fungus respectively. These were further incubated at $37^{\circ} \mathrm{C}$ for 18 hours and $30^{\circ} \mathrm{C}$ for 48 hours respectively. The inoculums were standardized by adjusting to $0.5 \mathrm{McFarland}$ turbidity (mixture of $99.5 \mathrm{ml}$ of $1 \%$ sulphuric acid and $0.5 \mathrm{ml}$ barium chloride) equivalents to $1.5 \times 10^{8} \mathrm{CFU} / \mathrm{mL}$ for bacteria and $2 \times 10^{5}$ spores $/ \mathrm{mL}$ for the fungus (Baris et al., 2006).

Then, susceptibility of the pathogenic bacteria (Staphylococcus aureus ATCC 25923 and Escherichia coli ATCC 25922) and fungi (Candida alblicans) to the different solvent extracts of of $A$. indica and $C$.papaya was tested by a modified disc diffusion assay described by Ncube et al. (2008). About $1 \mathrm{ml}$ each of standardized bacterial and fungal inoculums were separately introduced aseptically into separate sterilized Petri dishes then overlaid with $20 \mathrm{ml}$ Mueller-Hinton agar (MHA; Becton-Dickson, USA) for bacteria and Sabouraud dextrose agar (SDA) for the fungus respectively. The inoculated plates were swirled for even distribution of the inoculums within the agar medium then allowed to gel. The impregnated discs with the plant extracts were distributed on the inoculated agar surface $(22 \mathrm{~mm}$ from each other and $14 \mathrm{~mm}$ from the edge of the plate) using sterile forceps. The discs were gently pressed for uniform contact with the surface of the medium; the plates were allowed to stand on the bench for 30 minutes for proper diffusion of agent from the disc into the inoculated agar and incubated at $37^{\circ} \mathrm{C}$ for 24 hours for bacteria and at $30{ }^{\circ} \mathrm{C}$ for 24 hours for fungus. Commercially available antibiotics, Gentamycin at $30 \mu \mathrm{g}$ (Becton- Dickson, USA) and an antifungal drug (griseofulvin) were taken as a positive control and dissolved in distilled water $(30 \mu \mathrm{g} / 6 \mu \mathrm{L})$ while DMSO was incorporated as negative control. Clear zones around the discs were measured using with the aid of Vernier 
caliper $(\mathrm{mm})$ and recorded. This was done in triplicates and the average of the three replicates was calculated and recorded.

\section{Phytochemical screening}

Phytochemical screening for the presence of tannins, steroids, saponins, glycoside, terpenoid, protein, flavonoids, anthraquinone, alkaloid and coumarin was carried out according to the method described by Trease and Evans (2007).

\section{HPLC method}

HPLC analysis was carried out using the modified method of Springfied et al. (2005). A modular chromatographic system Shimadzu (Nexeramx) LC-10 comprising a LC-10AD pump, a CTO-10A column oven, a SPD-10A UV-DAD detector, a CBM-10A interface and a LC-10 Workstation was used. A LC-18 column ( $250 \mathrm{~mm} \times 4.6 \mathrm{~mm}$ ID x $5 \mathrm{~mm}$ ) from (Ubondapak, Bellefonte, USA) was employed at $30{ }^{\circ} \mathrm{C}$. Separations were done in the isocratic mode, using mobile phase acetonitrile: water (40:60 v/v) at a flow rate of $1 \mathrm{~mL} / \mathrm{min}$; with an injection volume ("loop") of $10 \mu \mathrm{L}$, UV detection was at $254 \mathrm{~nm}$.

\section{Results}

Percentage yield of acetone, hexane and ethyl acetate extracts of Carica papaya and Azadirachta indica after evaporation

Acetone (12.40\%), hexane (14.6\%) and ethylacetate (8.04\%) extracts of $A$. indica gave higher percentage yield, while low percentage yield was obtained for acetone (10.2\%), hexane (10.0\%) and ethylacetate $(8.0 \%)$ extracts of C. papaya (Figure 1).

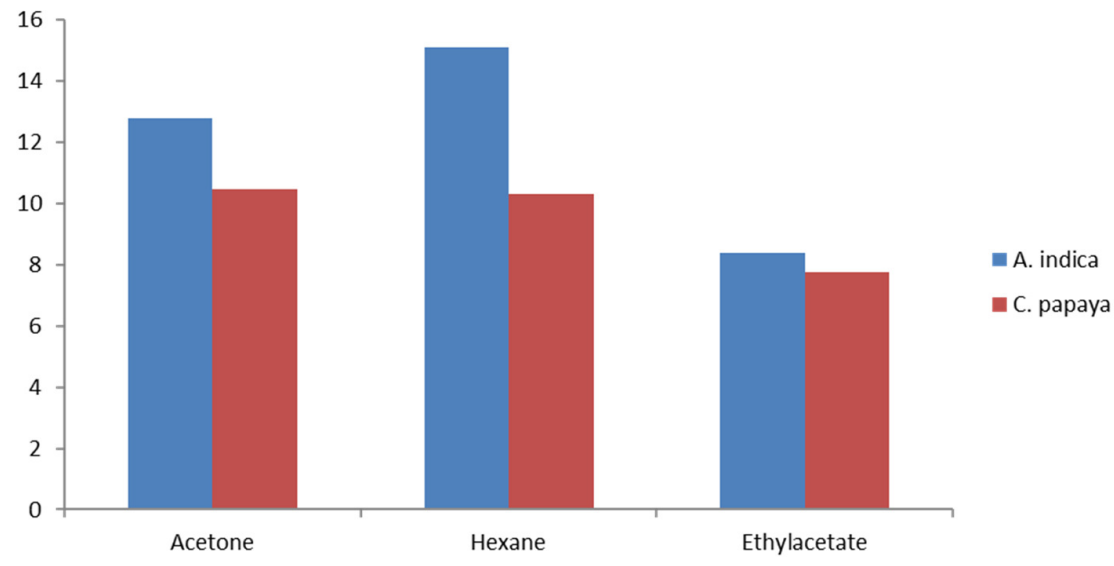

Figure 1. Percentage yield of acetone, hexane and ethyl acetate extracts of Carica papaya and Azadirachta indica leaves

Table 1 shows the result of phytochemical screening of all the solvent extracts of $A$. indica and C.papaya. Classes of compounds: tannin, steroid, saponin, anthraquinone and alkaloid were present in all the solvent extracts of $A$. indica and C. papaya. However, protein was present in all the solvent extracts of $A$. indica but absent in all the solvent extracts of $C$. papaya. Terpenoid was only present in hexane extract of $A$. indica but absent in all other solvent extracts of the plants. Flavonoid was present in all but absent in ethylacetate of $A$. indica. Glycoside was also present in all but absent in hexane extract of $A$. indica. Lastly, coumarin was only 
present in acetone extracts of both plants and absent in other solvent extracts of the two plants (Tables 2 and 3).

Table 1. Preliminary phytochemical constituents of acetone, hexane and ethylacetate extracts of Carica papaya and Azadirachta indica leaves

\begin{tabular}{|c|c|c|c|c|c|c|}
\hline \multirow{2}{*}{ Composition } & \multicolumn{2}{|c|}{ Acetone } & \multicolumn{2}{c|}{ Hexane } & \multicolumn{2}{c|}{ Ethylacetate } \\
\cline { 2 - 7 } & A. indica & C.papaya & A. indica & C.papaya & A. indica & C.papaya \\
\hline Tannin & + & + & + & + & + & + \\
\hline Steroid & + & + & + & + & + & + \\
\hline Saponin & + & + & + & + & + & + \\
\hline Glycoside & + & + & - & + & + & + \\
\hline Terpenoid & - & - & + & - & - & - \\
\hline Protein & + & - & + & - & + & - \\
\hline Flavonoid & + & + & + & + & - & + \\
\hline Anthraquinone & + & + & + & + & + & + \\
\hline Alkaloid & + & + & + & + & + & + \\
\hline Coumarin & + & + & - & - & - & - \\
\hline
\end{tabular}

Table 2. Constituents of different solvent extracts of Azadirachta indica separated by HPLC

\begin{tabular}{|c|c|c|c|c|c|c|}
\hline \multirow{2}{*}{ Component } & \multicolumn{2}{|c|}{ Acetone } & \multicolumn{2}{c|}{ Ethylacetate } & \multicolumn{2}{c|}{ Hexane } \\
\cline { 2 - 7 } & $\begin{array}{c}\text { Retention } \\
\text { (Mins) }\end{array}$ & Height & $\begin{array}{c}\text { Retention } \\
\text { (Mins })\end{array}$ & Height & $\begin{array}{c}\text { Retention } \\
\text { (Mins })\end{array}$ & Height \\
\hline Myricetin & 3.700 & 49.672 & 3.700 & 61.812 & 3.700 & 51.309 \\
\hline Azadirachtol & 5.883 & 7.817 & 5.883 & 11.408 & 5.883 & 10.159 \\
\hline Azadirachtin A & 7.996 & 12.452 & 7.966 & 14.708 & 7.966 & 12.939 \\
\hline Pentadecane & ${ }^{*}$ & ${ }^{*}$ & 9.116 & 2.910 & & \\
\hline Phytol & ${ }^{*}$ & ${ }^{*}$ & ${ }^{*}$ & ${ }^{*}$ & ${ }^{*}$ & ${ }^{*}$ \\
\hline Azadirachnol & 15.500 & 10.242 & 15.500 & 12.686 & 15.500 & 12.609 \\
\hline Quercetin & 17.233 & 30.220 & 17.233 & 35.938 & 17.233 & 35.708 \\
\hline B. Caryophyllen & ${ }^{*}$ & ${ }^{*}$ & 19.166 & 5.261 & 19.166 & 4.861 \\
\hline Alpha Ionone & ${ }^{*}$ & ${ }^{*}$ & ${ }^{*}$ & ${ }^{*}$ & ${ }^{*}$ & $*$ \\
\hline Alpha Funebren & 20.500 & 2.131 & 20.500 & 2.493 & 20.500 & 1.974 \\
\hline ASCARIDOLE & & & 21.416 & 1.959 & & \\
\hline Trams.B.Farnes & ${ }^{*}$ & ${ }^{*}$ & ${ }^{*}$ & ${ }^{*}$ & $*$ & \\
$*$
\end{tabular}

Table 3. Constituents of different solvent extracts of Carica papaya separated by HPLC

\begin{tabular}{|c|c|c|c|c|c|c|}
\hline \multirow{2}{*}{ Component } & \multicolumn{2}{|c|}{ Acetone } & \multicolumn{2}{c|}{ Ethylacetate } & \multicolumn{2}{c|}{ Hexane } \\
\cline { 2 - 7 } & $\begin{array}{c}\text { Retention } \\
\text { (mins) }\end{array}$ & Height & $\begin{array}{c}\text { Retention } \\
\text { (mins) }\end{array}$ & Height & $\begin{array}{c}\text { Retention } \\
\text { (mins) }\end{array}$ & Height \\
\hline Acacic acid & 1.266 & 29.889 & 1.266 & 28.971 & 1.266 & 28.070 \\
\hline Genistein & 2.700 & 22.482 & 2.700 & 19.927 & 2.700 & 17.419 \\
\hline Protodioscin & 4.600 & 9.166 & 4.600 & 4.589 & 4.600 & 2.427 \\
\hline Betulinic acid & 5.500 & 4.067 & $*$ & ${ }^{*}$ & ${ }^{*}$ & $*$ \\
\hline Phorbolester & 5.733 & 3.297 & 5.733 & 7.123 & ${ }^{*}$ & ${ }^{*}$ \\
\hline Creptolepinone & 11.116 & 146.389 & 11.116 & 139.485 & 11.116 & 137.631 \\
\hline Brusatol & 12.216 & 57.652 & 12.216 & 44.250 & 12.216 & 40.454 \\
\hline Alpha ionone & 13.816 & 38.442 & 13.816 & 15.417 & 13.816 & 8.795 \\
\hline
\end{tabular}


Figures 2 and 3 showed the results of susceptibility test of the extracts on the test pathogenic microorganisms. All the solvent extracts of $A$. indica and $C$. papaya were generally observed to have irregular pattern of activities at all the tested concentrations. Although in Figure 2, the activity of $A$. indica was highest for acetone extracts at $25 \mathrm{mg} / \mathrm{mL}$ concentration against $E$. coli and lowest for acetone and ethyl acetate at 50 $\mathrm{mg} / \mathrm{mL}$ against $E$. coli respectively.

In Figure 3, highest activity was obtained for ethylacetate extract $($ at $50 \mathrm{mg} / \mathrm{mL})$ and hexane extract (at $25 \mathrm{mg} / \mathrm{mL}$ ) of $C$. papaya against $E$. coli and Candida respectively while lowest activity was obtained for $50 \mathrm{mg}$ $/ \mathrm{mL}$ of hexane extract (against all the test organisms), ethyl acetate (against $E$. coli) and at $25 \mathrm{mg} / \mathrm{mL}$ of acetone extract against $E$. coli.

Figure 4 shows the comparative results obtained for the control agents (gentamicin and griseofulvin) and the highest zones of inhibition obtained for the solvent extracts of $A$. indica and $C$. papaya against the test organisms. Highest zone of inhibition $(28 \mathrm{~mm})$ was obtained by gentamicin, followed by griseofulvin and $C$. papaya respectively $(18 \mathrm{~mm})$ while $A$. indica gave the least zone of inhibition $(15 \mathrm{~mm})$.

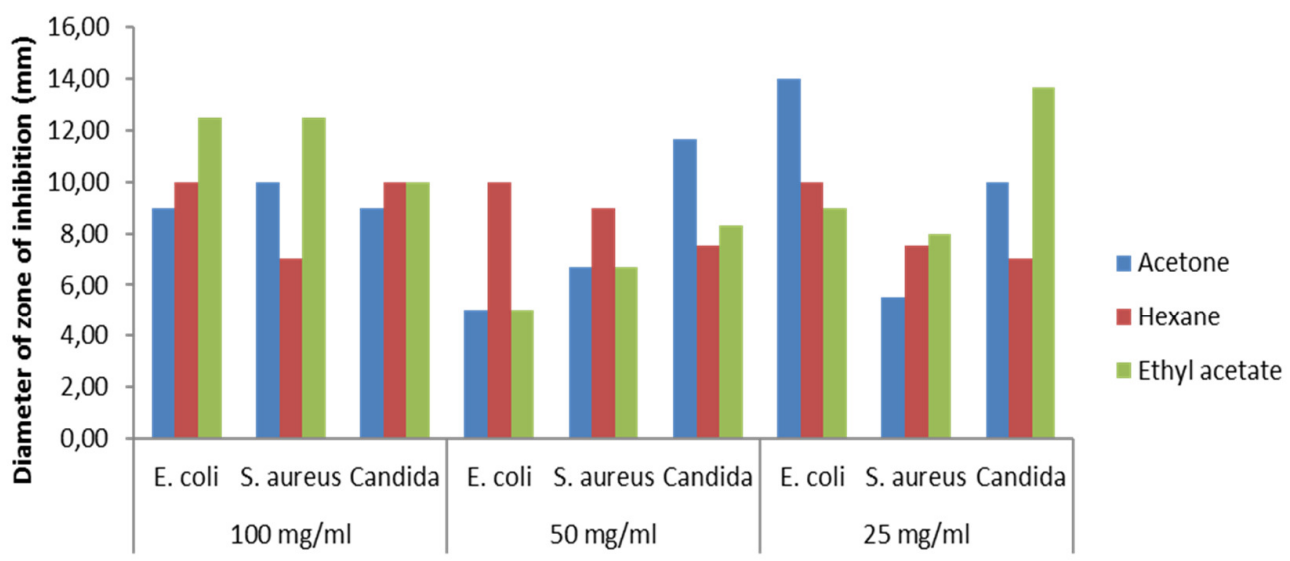

Concentration of Plant extract against test organism

Figure 2. Average zones of inhibition of different concentrations of $A$. indica leaves against the tested microorganisms

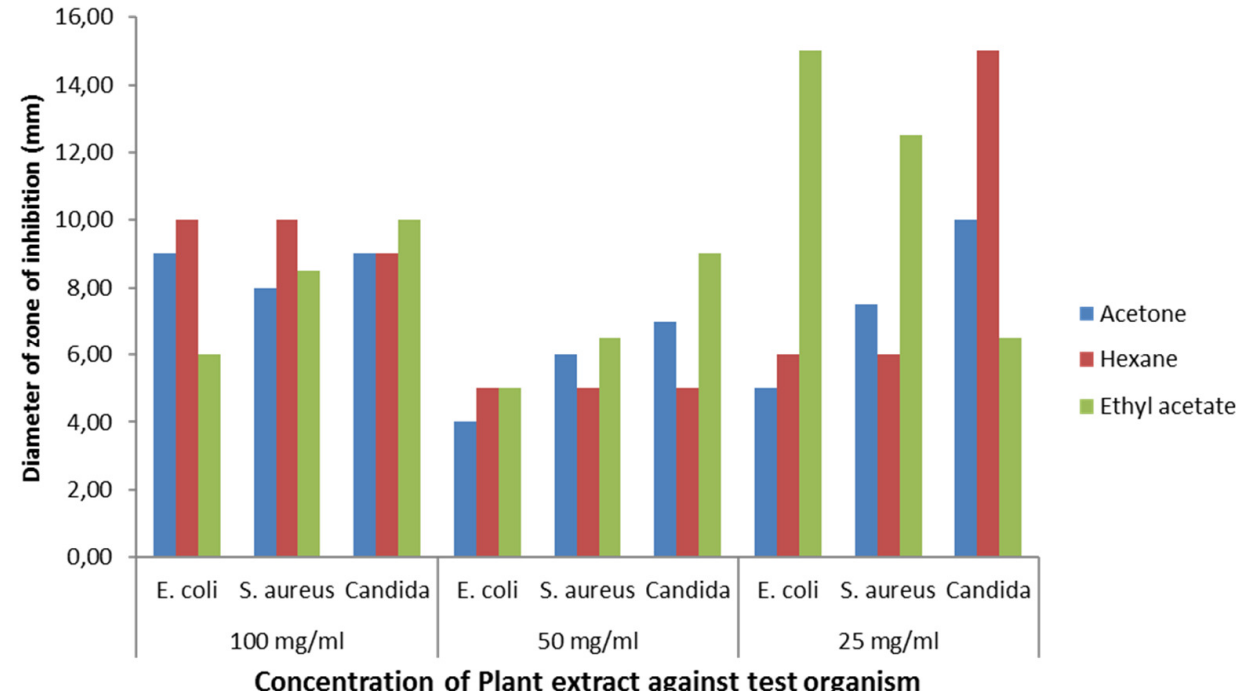

Figure 3. Average zones of inhibition of different concentrations of $C$. papaya leaves against the tested microorganisms 


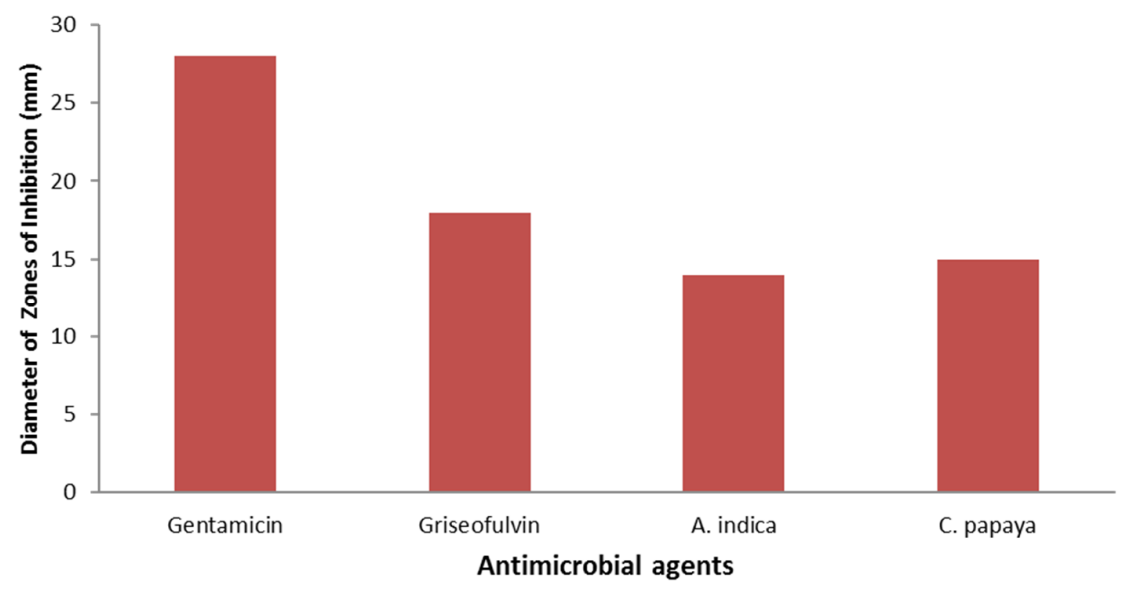

Figure 4. Comparison between highest effects produced by plant extracts and the commercial drugs

Chromatogram of hexane extracts of $C$. papaya leaves as visualized in the form of peak showed six fractions of compounds namely: acacic acid, genistein, protodioscin, creptolephone, brusatol and alpha ionone. These compounds separated based on their unique chemistry; the peaks had the heights of 28.070, 17.410, $2.427,137.631,40.454,8.705 \%$. Creptolephone had highest sharp peak 137.631 at $11.116 \mathrm{~min}$. retention time $(\mathrm{Rt})$. Brustanol had the next sharp peak 40.14 at retention time $(\mathrm{Rt}) 12.216 \mathrm{~min}$. The height peak of acacic acid was 28.070 at $1.266 \mathrm{Rt}$. The next chromatogram peak of 17.410 denoted genistein at Rt 2.700, the height of alpha ionone was 8.705 at Rt 12.210 and 2.427 height for protodioscin at Rt 4.600 (Figure 5).

Chromatogram of hexane extracts of Azadirachta indica leaves as visualized in the form of peak showed seven fractions of compounds namely: myricetin, azadiracthtol, azadirachtin a, azadiractnol, quercetin, b-caryophyllen, alpha funebren. These compounds separated based on their unique chemistry; the peaks had the heights of $51.309,10.159,12.939,12.609,35.708,4.861,1.974 \%$. Myricetin had highest sharp peak 51.309 at 3.700 min. retention time (Rt). Quercetin had the next sharp peak 35.708 at retention time (Rt) 17.233 min. The height peak of azadirachtin a was 12.939 at 7.966 Rt. The next chromatogram peak of 12.609 was azadiractnol at $15.500 \mathrm{Rt}$, azadiracthtol had height peak of 10.159 at Rt 5.883. B-caryophyllen height peak as 4.861 at $19.166 \mathrm{Rt}$ and Alpha funebren had height peak of 1.974 at $20.500 \mathrm{Rt}$ (Figures 6, 7, 8, 9, 10).

\section{Discussion}

Leaves of $A$. indica and C.papaya used in this study were air dried to get rid of moisture which may affect the solubility of subsequent separation by extraction and the secondary metabolites in plants may become unstable as a result of moisture, especially if the plant is to be used as an antimicrobial agent. It has been reported that plants are usually air dried to a constant weight to get rid of moisture (Dilika et al., 1996; Baris et al., 2006). Higher percentage yield was obtained for all the solvent extracts of $A$. indica than extracts of $C$. papaya. In order to extract different phenolic compounds from plants with a high degree of accuracy, various solvents of differing polarities must be used (Wong and Kitts, 2006). Takazawa et al. (1982) also stated that there is a need to employ broad range of extractive solvents in the extractions of possible phytochemicals from medicinal plants. Hence, this study involved the use of acetone, hexane and ethyl acetate. Parekh et al. (2006) reported that traditional healers use primarily water for extraction but plant extracts from organic solvents have been 
64

found to give more consistent antimicrobial activity compared to water extracts. All the solvents used for extraction of biomolecules from plants are chosen based on the polarity of the solute of interest. Although, the solvents used in this study are not very commonly used, acetone for example has been used by a number of authors (Basri and Fan, 2005; Mathkega et al., 2006). The most commonly used solvents for investigations of antimicrobial activity in plants are methanol, ethanol, and water (Parekh et al., 2006; Bisignino et al., 1999; Salie et al., 1996; Rojas et al., 2006). In a study conducted by Masoko and Eloff (2006) on antifungal activities of different solvent (hexane, dichloromethane, acetone and methanol) extracts of Combretum species, it was discovered that acetone and methanol extracted more chemical compounds from the leaves than other solvents.

Temperature program:
Init temp Hold Ramp Final temp
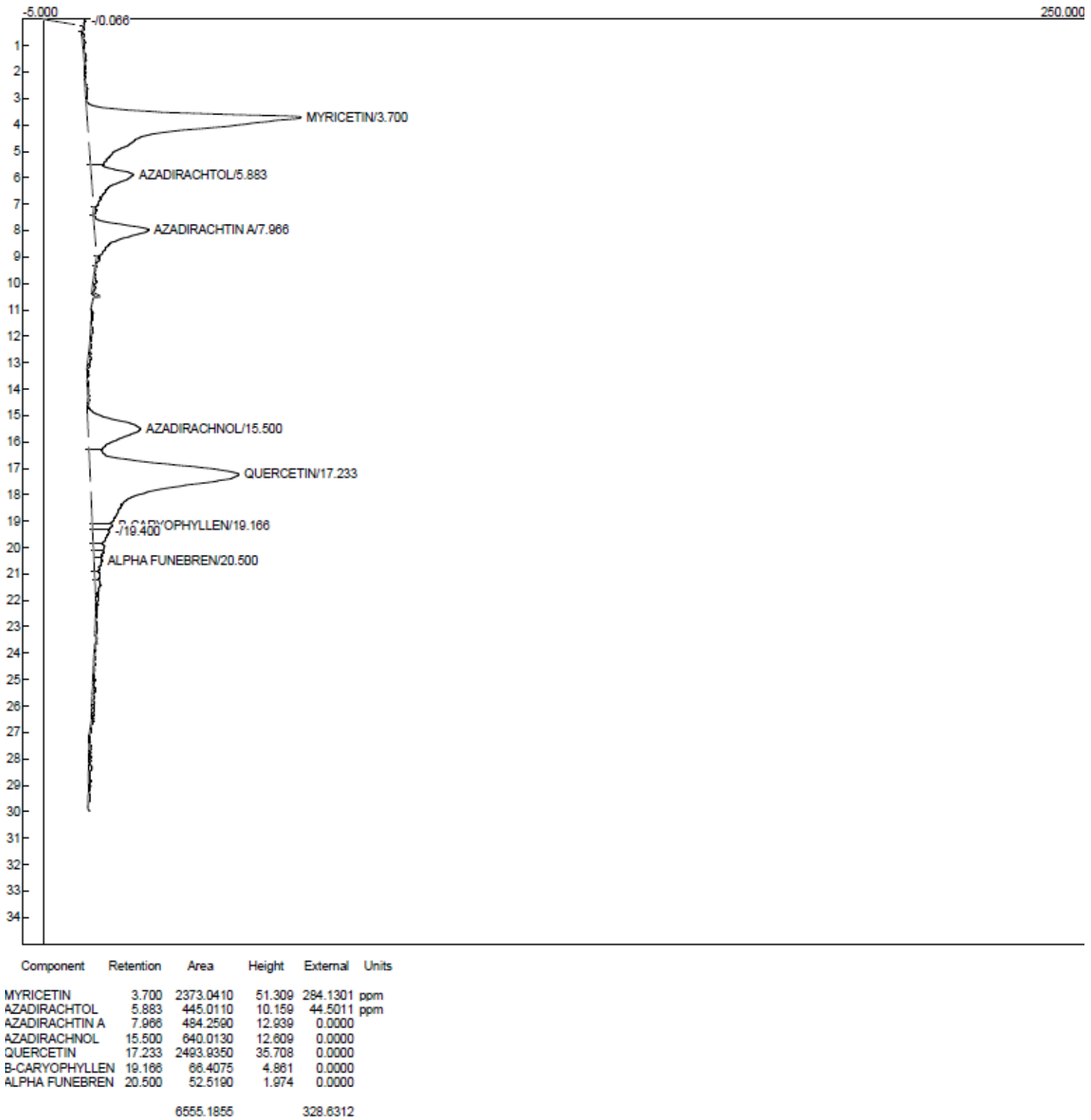

Figure 5. Chromatogram of acetone extract of $A$. indica leaves 


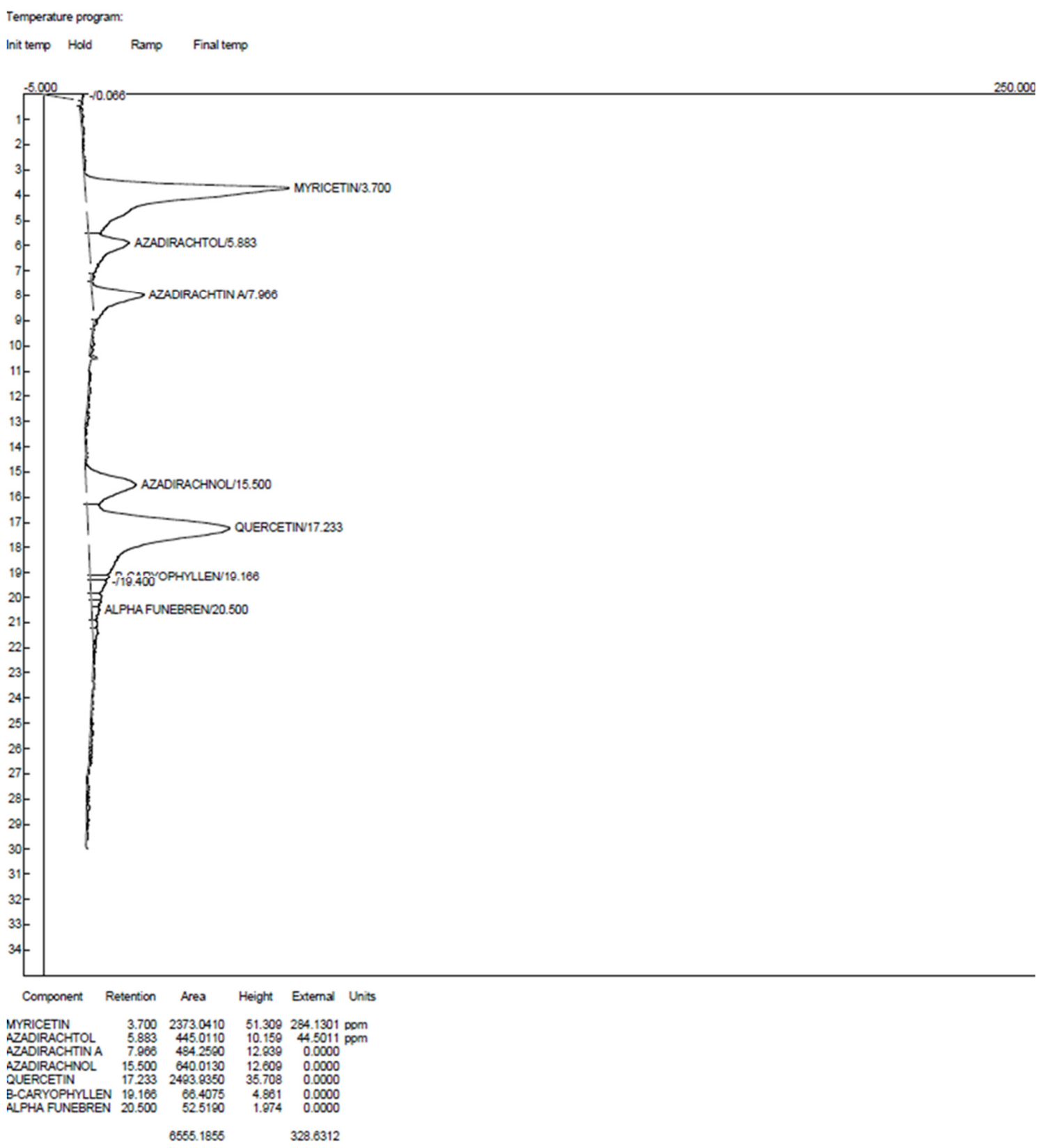

Figure 6. Chromatogram of hexane extract of $A$. indica leaves 


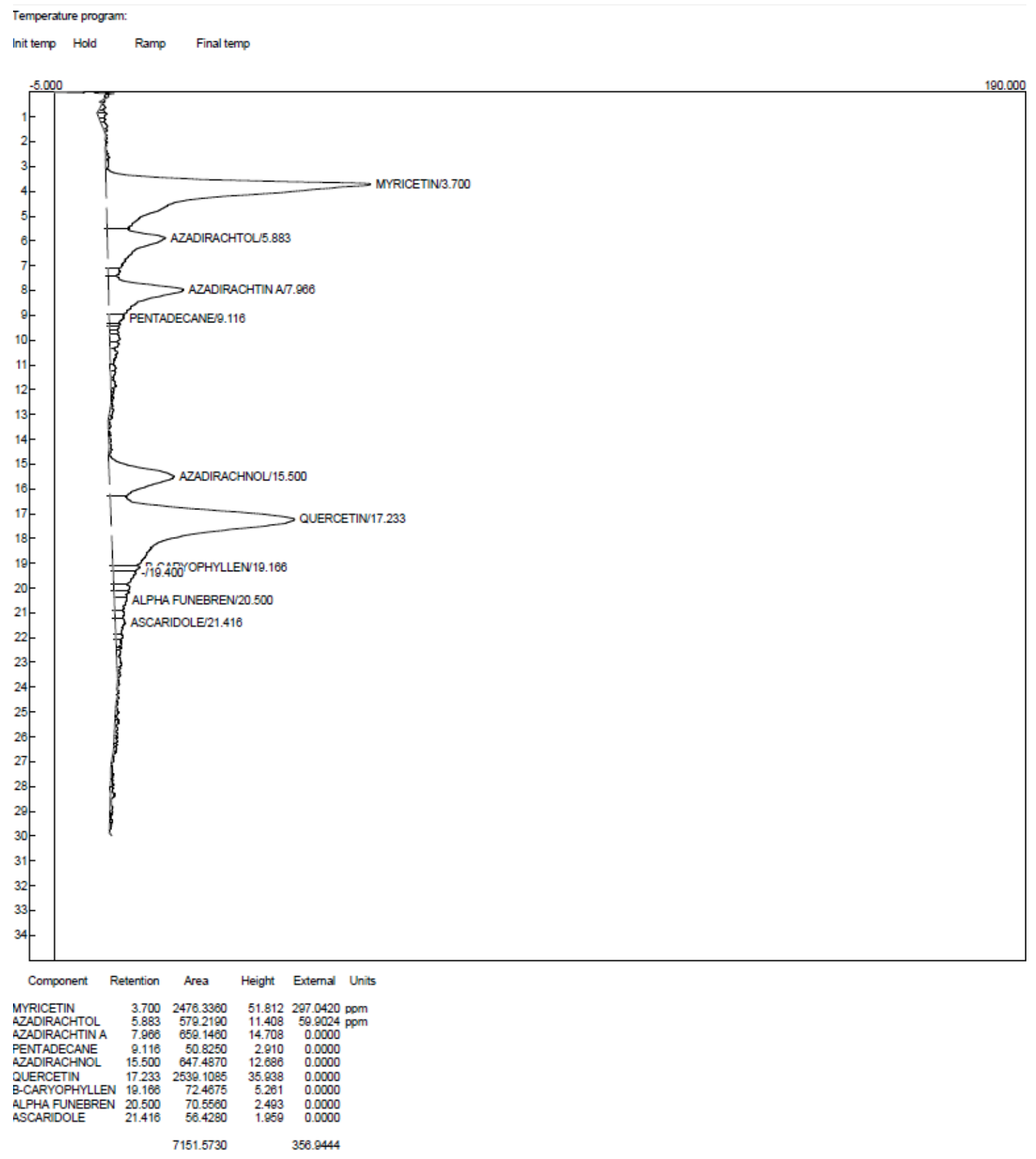

Figure 7. Chromatogram of ethylacetate extract of $A$. indica leaves 


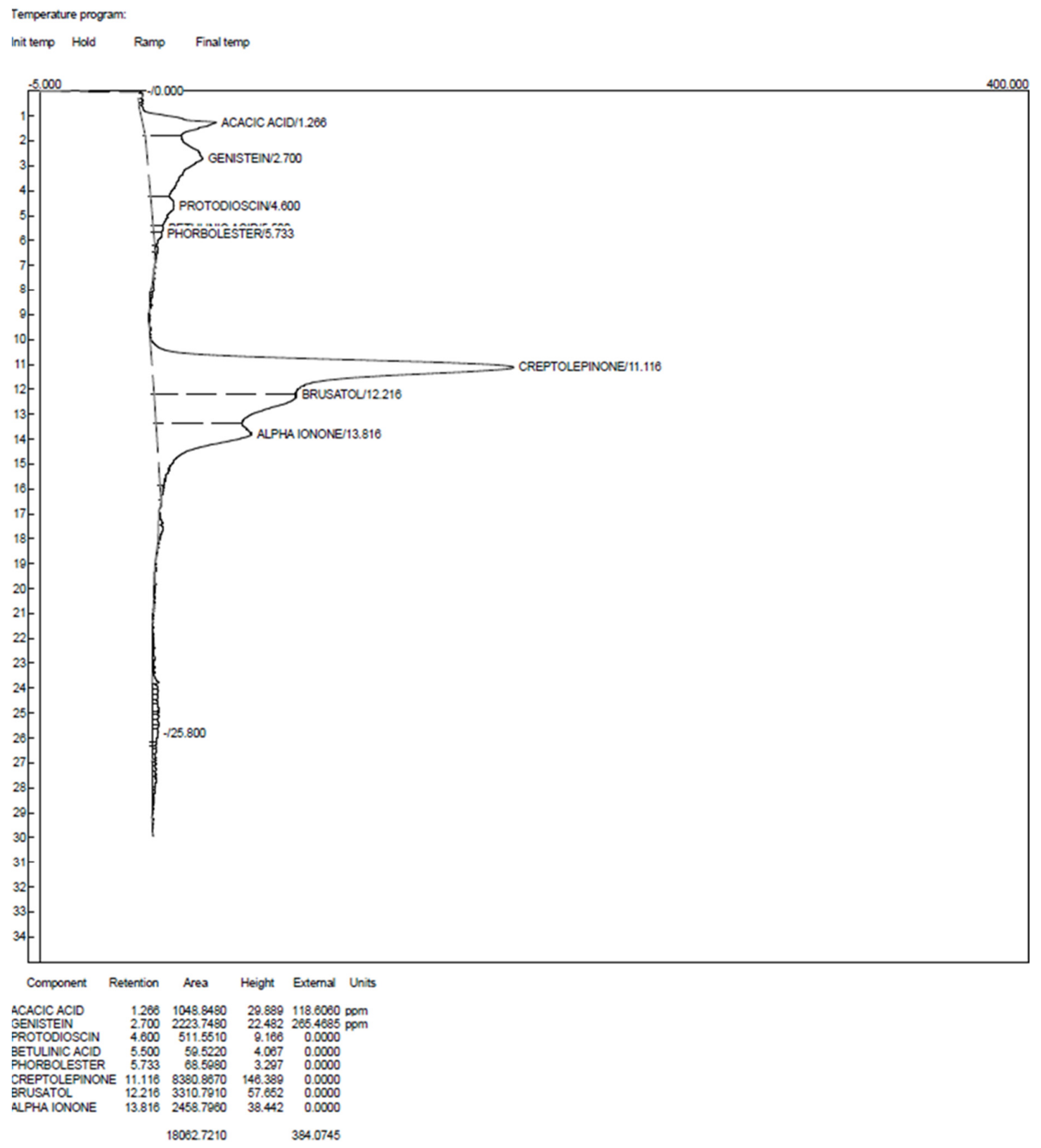

Figure 8. Chromatogram of acetone extract of $C$. papaya leaves 


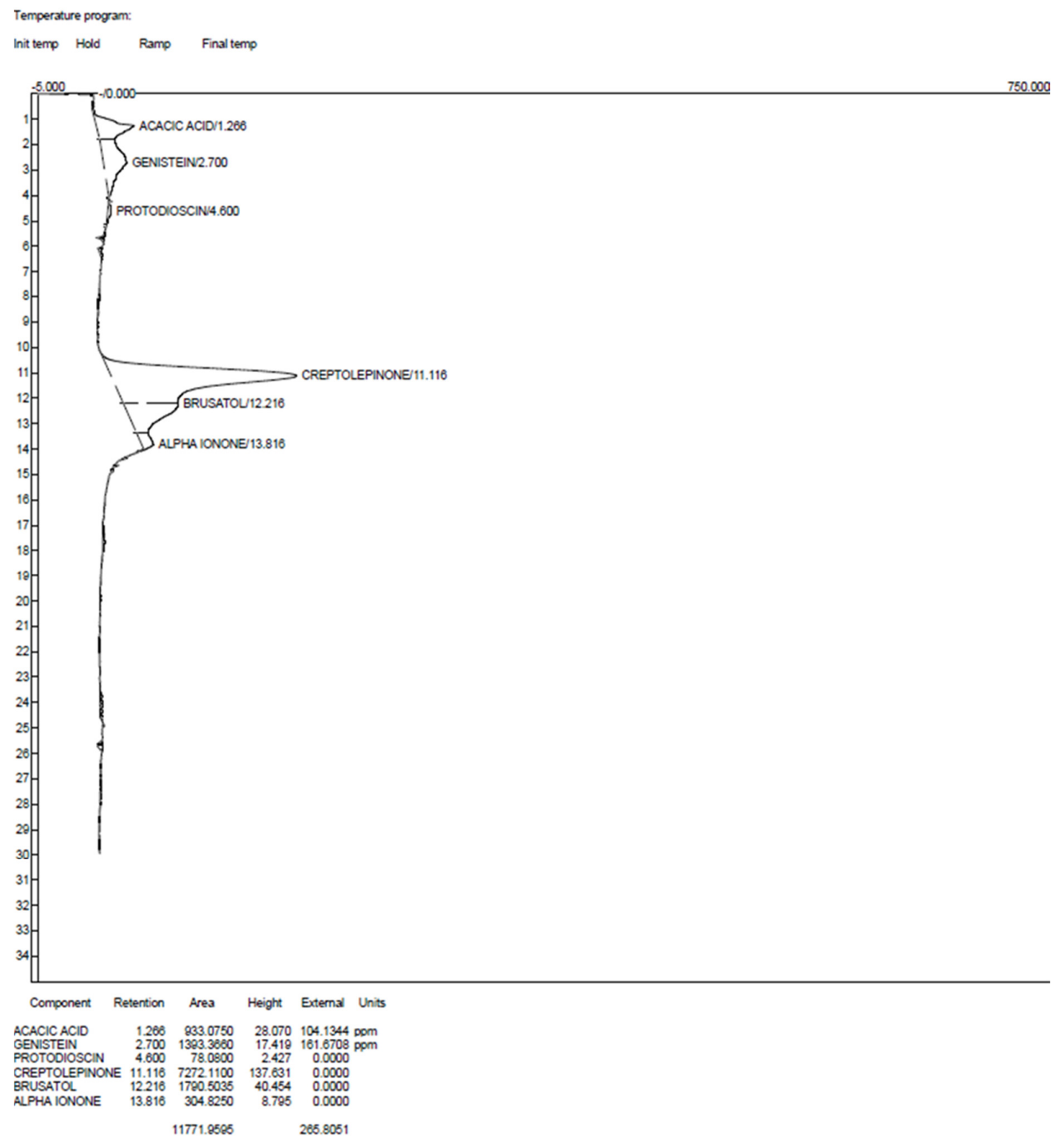

Figure 9. Chromatogram of hexane extract of $C$. papaya leaves 


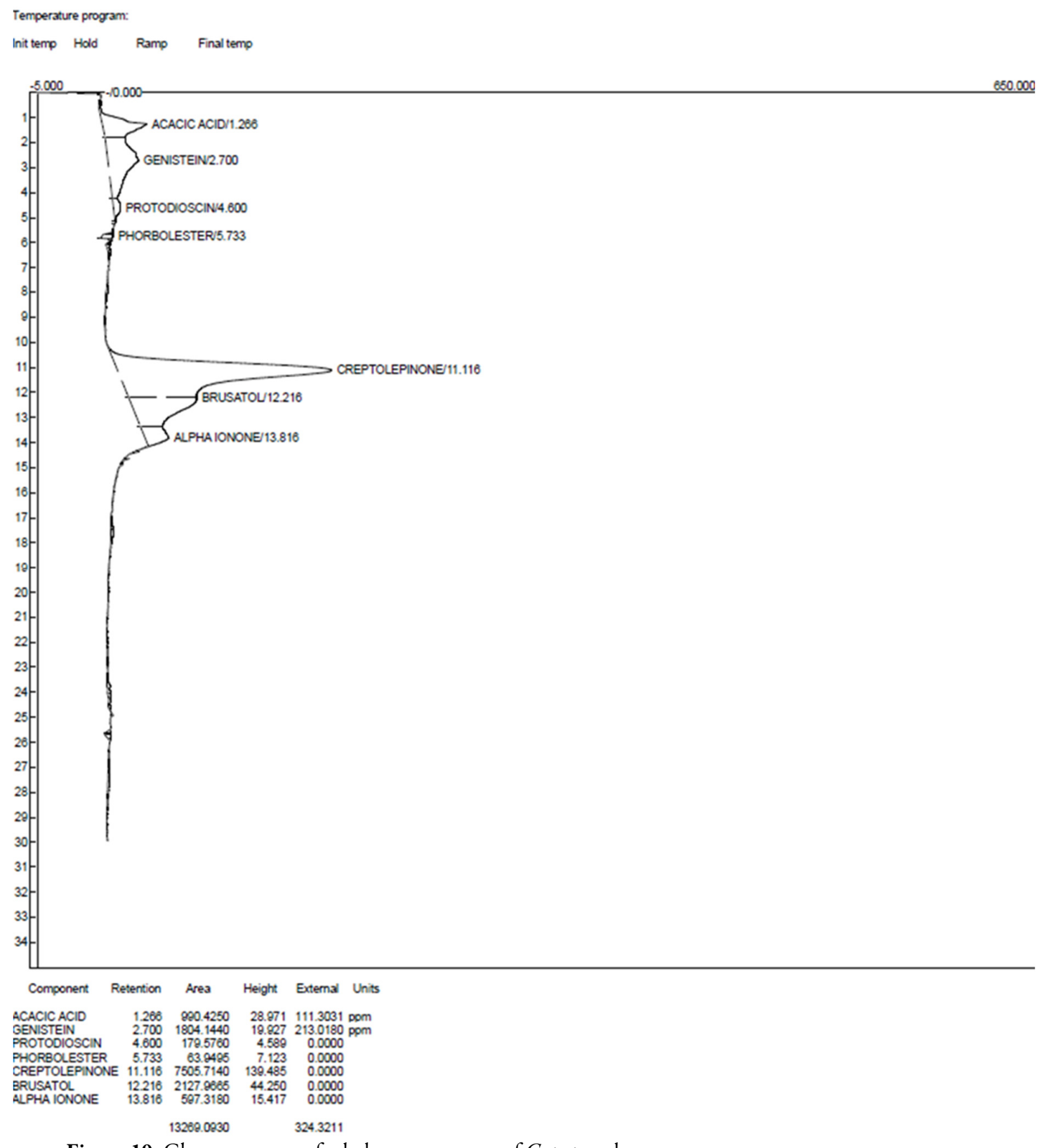

Figure 10. Chromatogram of ethyl acetate extract of $C$. papaya leaves

Eloff (1998) examined a variety of extractants for their ability to solubilize antimicrobials from plants, their rate of extraction, their ease of removal, their toxicity in bioassay, among other things, and acetone received the highest overall rating. Anokwuru et al. (2011) reported that acetone and N, N dimethylformamide (DMF) are highly effective at extracting antioxidants, while Koffi et al. (2010) reported that methanol was more effective at extracting large amount of phenolic compounds from walnut fruits when compared to ethanol. 
Findings in this work recorded strong occurrence of antimicrobial compounds (saponins, steroid, tannin, anthraquinone, glycoside, protein, flavonoids). Tannin, alkaloid, steroid, saponin and anthraquinone were present in all the solvent extracts of $A$. indica and C. papaya. Enyi-Idoh et al. (2012) also reported that Vernonia amygdalina have ample quantities of saponins, flavonoids, alkaloids and tannins. It has been reported that phytochemical substances such as alkaloids, saponins, tannins, flavonoids, alkaloids, flavonoids, and terpenoids are bioactive bases responsible for antibacterial property by exerting bacteriostatic and bactericidal effects on some bacteria (Obadoni and Ochuko, 2001; Okigbo and Ogbonnanya, 2006; Funmilayo et al., 2010). According to Ogundare et al. (2006), saponins, flavonoids, tannins and anthraquinones found in bitter leave were reported to have very potent antibacterial effect.

Variable antimicrobial activities were recorded for different solvent extracts of $A$. indica and C. papaya against Staphylococcus aureus ATCC 25923, Escherichia coli ATCC 259220 and Candida albicans. Although, solvent extracts of the plants showed no regular pattern of activities against the test pathogens and this concurs with the report that different organisms respond differently to different and same concentrations of a specific medicinal plant (Arekemase et al., 2013). Antimicrobial activities observed in this work maybe imputable to the antimicrobial compounds detected in this work. All extracts tested exhibited dose dependent antimicrobial activities against the test organisms (E. coli ATCC 25922, Staphylococcus aureus ATCC 25923 and C. albicans). Arekemase et al. (2013) has also demonstrated antimicrobial activity of Vitellaria paradoxa extract against bacteria. The lowest concentration of the extracts tested was displayed inhibitory effects against the test organisms; the effects produced by commercial antibiotics was still higher than what was obtained for the plants under study. This maybe because plants comprise array of compounds which are in mixtures in contrast to the pure compound contained in the commercial agents (Gatsing et al., 2010). Findings in this work are in line with the work of Eja et al. (2011), who reported significant antimicrobial activities of Vernonia amygdalina on E. coli and Staphylococcus aureus.

Antimicrobial activities demonstrated by hexane and ethylacetate extracts of $C$. papaya may be attributed to the presence of flavonoid which was not present in ethylacetate extract of $A$. indica and glycosides which were also not present in hexane extract of $A$. indica. Although, terpenoid was only present in hexane extract of $A$. indica but absent in all other solvent extracts.

Several fractions of flavonoids and phenolic compounds were comparatively separated in the different solvent extracts of $C$. papaya and $A$. indica as different peaks and quantified by HPLC. Variation in the retention times within different extracts indicated the presence of phytochemicals in $C$. papaya extracts as acacic acid, genistein, protodioscin, betulinic acid, phorbolester, creptolepinone, brusatol and alpha ionone while the fractions from the solvent extracts of Azadirachta indica are myricetin, azadirachtol, azadirachtin a, pentadecane, phytol, azadirachnol, quercetin, b. caryophyllen, alpha ionone, ascaridole, trams.b.farnes. However, this variation has also been reported in scientific literature (Asen, 1984). It has been reported that ethanolic extracts of Ivorian plants extracted higher concentrations/amount of phenolics compared to acetone, water, and methanol (Koffi et al., 2010).

\section{Conclusions}

Results obtained in this work indicated that all the solvent extracts of Carica papaya and Azadirachta indica contained numerous active phytoconstituents and the extracts displayed good potentials at preventing diseases associated with the microorganisms tested in this work. Hence, it can be concluded that the plants are useful medicinally as broad-spectrum antimicrobial agents. The antimicrobial properties of these plants can therefore be credited to the presence of active constituents suggesting that the plants can serve as potential 
sources of alternative antimicrobial agents. This work suggests further research on the dosage and safety of these medicinal plants on vital organs of the consumer.

\section{Acknowledgements}

This research received no specific grant from any funding agency in the public, commercial, or not-forprofit sectors.

\section{Conflict of Interests}

The authors declare that there are no conflicts of interest related to this article.

\section{References}

Alain DPB, Ernest K, Félix H, Yapi AAY, Joseph AD, Frédéric G (2010). Evaluation of the toxicity of a methanolic total extract of Mitragyna ciliataa natural antimalaric. International Journal of Biological and Chemical Science 4(3):770-781.

Amazu LU, Azikiwe CCA, Njoku CJ, Osuala FN, Nwosu PJC, Ajugwo AO, Enye JC (2010). Anti-inflammatory activity of the methanolic extract of the seeds of Carica papaya in experimental animals. Asian Pacific Journal of Tropical Medicine 3(11):884-886.

Anokwuru CP Anyasor GN, Ajibaye O, Fakoya O, Okebugwu P (2011). Effect of extraction solvents on phenolic, flavonoid and antioxidant activities of three Nigerian medicinal plants. Natural Science 9:53-61.

Arekemase MO, Oyeyiola GP, Balogun KI (2013). Assessment of Vernonia amygdalina on some selected pathogenic microorganisms from university of Ilorin teaching hospital. Journal of Microbiology, Biotechnology and Food Sciences 2(5):2360-2365.

Asen S (1984). High pressure liquid chromatography analysis of flavonoid chemical markers in petals from Gerbera flowers as an adjunct for cultivar and germplasm identification. Phytochemistry 23(11):2523-2526.

Baris O, Gulluce M, Sahin F, Ozer H, Kilic H, Ozkan H, ... Ozbek T (2006). Biological activities of the essential oil and methanol extract of Achillea Biebersteinii Afan. (Asteraceae). Turkish Journal of Biology 30:65-73.

Basri DF, Fan SH (2005). The potential of aqueous and acetone extracts of galls of Quercus infectoria as antibacterial agents. Indian Journal of Pharmacolology 37(1):26-29.

Bibi Y, Nisa S, Chaudhary F, Zia M (2011). Antibacterial activity of some selected medicinal plants of Pakistan. BMC Complementary Alternative Medicine 11:892-897.

Bisignino G, Sanogo R, Marino A, Aquino R, D'angelo V, Germano MP, ... Pizza C (1999). Antimicrobial activities of Mitracarpus scaber extract and isolated constituents. Letters in Applied Microbiology 30:105-108.

Boligon AA, Brum TF, Frohlich JK, Froeder ALF, Athayde ML (2012). HPLC/DAD profile and determination of total phenolics, flavonoids, tannins and alkaloids contents of Scutia buxifolia Reissek stem bark. Research Journal of Phytochemistry 6:84-91.

Dilika F, Afolayan AJ, Meyer JJM (1996). Comparative antibacterial activity of two Helichrysum species used in male circumcision in South Africa. South African Journal of Botany 63(3):158-159.

Eja ME, Arikpo GE, Enyi-Idoh KH, Ikpeme EM (2011). An evaluation of the antimicrobial synergy of garlic (Allium sativum) and Utazi (Gongronema latifolium) on E. coli and S. aureus. Malaysian Journal of Microbiology 7(1):4549.

Ekam VS, Ebong PE, Umoh IB (2010). Phytochemical screening of activity directed extracts of Vernonia amygdalina leaves. Global Journal of Pure and Applied Sciences 16(1):151-154.

Eloff JN (1998). A sensitive and quick microplate method to determine the minimum inhibitory concentration of plant extracts for bacteria. Planta Medica 64:711-713. 
72

Enyi-Idoh KH, Utasalo SJ, Epoke J, Arikpo GE, Eja ME (2012). Time-dependent evaluation of the antimicrobial and phytochemical properties of Vernonia amygdalina and Gongronema latifolium. The Internet Journal of Herbal and Plant Medicine 1(2):97-102.

Funmilayo VD, Olaniran OO, Kanife UC (2010). Antimicrobial activities of Aframomum melegueta (Alligator pepper). International Journal of Biology 2(2):126-131.

Gatsing D, Nkeugoauapi CFN, Nkah BFN, Kuiate JR, Tchouanguep FM (2010). Antibacterial activity, bioavailability and acute toxicity evaluation of the leaf extract of Alchornea cordifolia (Euphorbiaceae). International Journal of Pharmacology 6:173-182.

Goyal M, Nagori BP, Sasmal D (2008). Sedative and anticonvulsant effects of an alcoholic extract of Capparis decidua. Journal of Natural Medicines 63:375-379.

Gurunga S, Škalko-Basnet N (2009). Wound healing properties of Carica papaya latex: In vivo evaluation in mice burn model. Journal of Ethnopharmacology 121:338-341

Jawetz M, Adelberg S (2004). Medical microbiology. $3^{\text {rd }}$ Edition. Churchill and Livingstone, Longman Group Limited, United Kingdom.

Koffi E, Sea T, Dodehe Y, Soro S (2010). Effect of solvent type on extraction of polyphenols from twenty-three Ivorian plants. Journal of Animal and Plant Sciences 5:550-558.

Mahesh B, Satish S (2008). Antimicrobial activity of some important medicinal plants against plant and human pathogens. World Journal of Agricultural Sciences 4:839-843.

Masoko P, Eloff JN (2006). Bioautography indicates the multiplicity of antifungal compounds from twenty-four Southern African Combretum species (Combretacea). African Journal of Biotechnolology 5(18):1625-1647.

Mathekga ADM, Meyer JJM, Horn MM, Drewes SE (2000). An acylated phloroglucinol with antimicrobial properties from Helichrysum caesptitium. Phytochemistry 53:93-96.

Michiels JA, Kevers C, Pincemail J, Defraigne JO, Dommes J (2012). Extraction conditions can greatly influence antioxidant capacity assays in plant food matrices. Food Chemistry 130(4):986-993.

Mohammad A, Shohreh S, Amirhossein A, Maryam G, Mohammad S (2010). Antidiabetic effects of aqueous fruits extract of Diospyros lotus L. on streptozotocin-induced diabetic rats and the possible morphologic changes in the liver, kidney and heart. Journal of Pharmacognosy 2(2):010-016.

Ncube N, Afolayan SA, Okoh AI (2008). Assessment techniques of antimicrobial properties of natural compounds of plant origin: current methods and future trends. African Journal of Biotechnology 7:1797-1806.

Obadoni BO, Ochuko PO (2001). Phytochemical studies and comparative efficacy of the crude extract of some homeostatic plants in Edo and Delta states of Nigeria. Global Journal of Pure and Applied 8:203-208.

Ochei JO, Kolhatkar (2008). Medical laboratory science theory and practice. Tata McGrawHill Publishing Company, New York pp 603.

Ogundare AO, Adetuyi FC, Akinyosoye FA (2006). Antimicrobial activities of Vernonia tenoriana, African Journal of Biotechnology 5(18):1663-1668.

Okigbo RN, Ogbonnanya OU (2006). Antifungal effects of two tropical plants extract Ocimum gratissimum and Afromaomum melegueta on post-harvest yam Discorea spp. rot. African Journal of Biotechnology 5(9):727-731.

Perez C, Pauli M, Bazevque P (1990). An antibiotic assay by the agar well diffusion method. Acta Biologiae et Medicinae Experimentalis 15:113-115.

Philip K, Malek SNA, Wirakarnain S, Sim KS, Saravana K, Hong SL, ... Syarifah NSA (2009). Antimicrobial activity of some medicinal plants from Malaysia. American Journal of Applied Sciences 6(8):1613-1617.

Rojas JJ, Ochoa VJ, Ocampo SA, Monoz JF (2006). Screening for antimicrobial activity of ten medicinal plants used in Colombian folkloric medicine: a possible alternative in treatment of nonnosocomial infections. BMC Complementary Alternative Medicine 6:2.

Salie F, Eagles PFK, Lens HMJ (1996). Preliminary antimicrobial screening of four South African Asteraceae species. Journal of Ethnopharmacology 52(1):27-33.

Shariff ZU (2001). Modern herbal therapy for common ailments. Nature Pharmacy Series (Volume 1), Spectrum Books Limited, Ibadan, Nigeria in Association with Safari Books (Export) Limited, United Kingdom pp 9-84.

Springfield EP, Eagles PKF, Scott G (2005). Quality assessment of south African herbal medicines by means of HPLC fingerprinting. Journal of Ethnopharmacology 101:75-83.

Takazawa H, Tajima F, Miyashifa C (1982). An antifungal compound from shitake (Lentinus edodes) Yakugaku zasshi Journal of the Pharmaceutical Society of Japan 102(5):489-491. 
Titanji VP, Zofou D, Ngemenya MN (2008). The antimalarial potential of medicinal plants used for the treatment of malaria in Cameroonian folk medicine. African Journal of Traditional Complementary and Alternative Medicines 5(3):302-321.

Trease GE, Evans WO (2007). Pharmacology. 11th Ed. Bailliere Tindall Ltd, London. (1989) pp 60-75.

Wong PYY, Kitts DD (2006). Studies on the dual antioxidant and antibacterial properties of parsley (Petroselinum crispum) and cilantro (Coriandrum sativum) extracts. Food Chemistry 97:505-515.
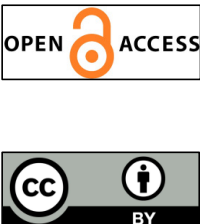

The journal offers free, immediate, and unrestricted access to peer-reviewed research and scholarly work, due SHST supports to increase the visibility, accessibility and reputation of the researchers, regardless of geography and their budgets. Users are allowed to read, download, copy, distribute, print, search, or link to the full texts of the articles, or use them for any other lawful purpose, without asking prior permission from the publisher or the author.

License - Articles published in Notulae Scientia Biologicae are Open-Access, distributed under the terms and conditions of the Creative Commons Attribution (CC BY 4.0) License.

(c) Articles by the authors; SHST, Cluj-Napoca, Romania. The journal allows the author(s) to hold the copyright/to retain publishing rights without restriction. 